Ann. rheum. Dis. (1955), 14, 170.

\title{
EFFECTS OF 9-ALPHA-FLUORO HYDROCORTISONE ACETATE ON ADRENAL FUNCTION
}

BY

\author{
H. F. WEST
}

From the Sheffield Centre for the Investigation and Treatment of Rheumatic Diseases

(RECEIVED FOR PUBLICATION JANUARY 19, 1955)

Boland and Headley (1954) described their clinical trials of 9- $a$-fluoro hydrocortisone acetate (9-a-fF) in the treatment of rheumatoid arthritis. Although salt-retention made the use of this drug in the treatment of rheumatoid arthritis impracticable, they saw in it a new hope, since its existence demonstrated the possibility of producing analogues of hydrocortisone with physiological properties differentially enhanced. The properties studied were the "antiinflammatory" (anti-rheumatoid in this instance) and the salt retaining. The former was approximately ten times as great as that of hydrocortisone and the latter more like fifty times as great. How does theO 9- $a$-fluoro substitution affect the adrenocorticab suppressive action? It would be a great advantageto have a cortisone-like steroid that would supple $\bar{c}$ ment the adrenocortical secretion instead of sup pressing it and providing a single qualitatively different substitute.

The Figure shows the results of an experiment

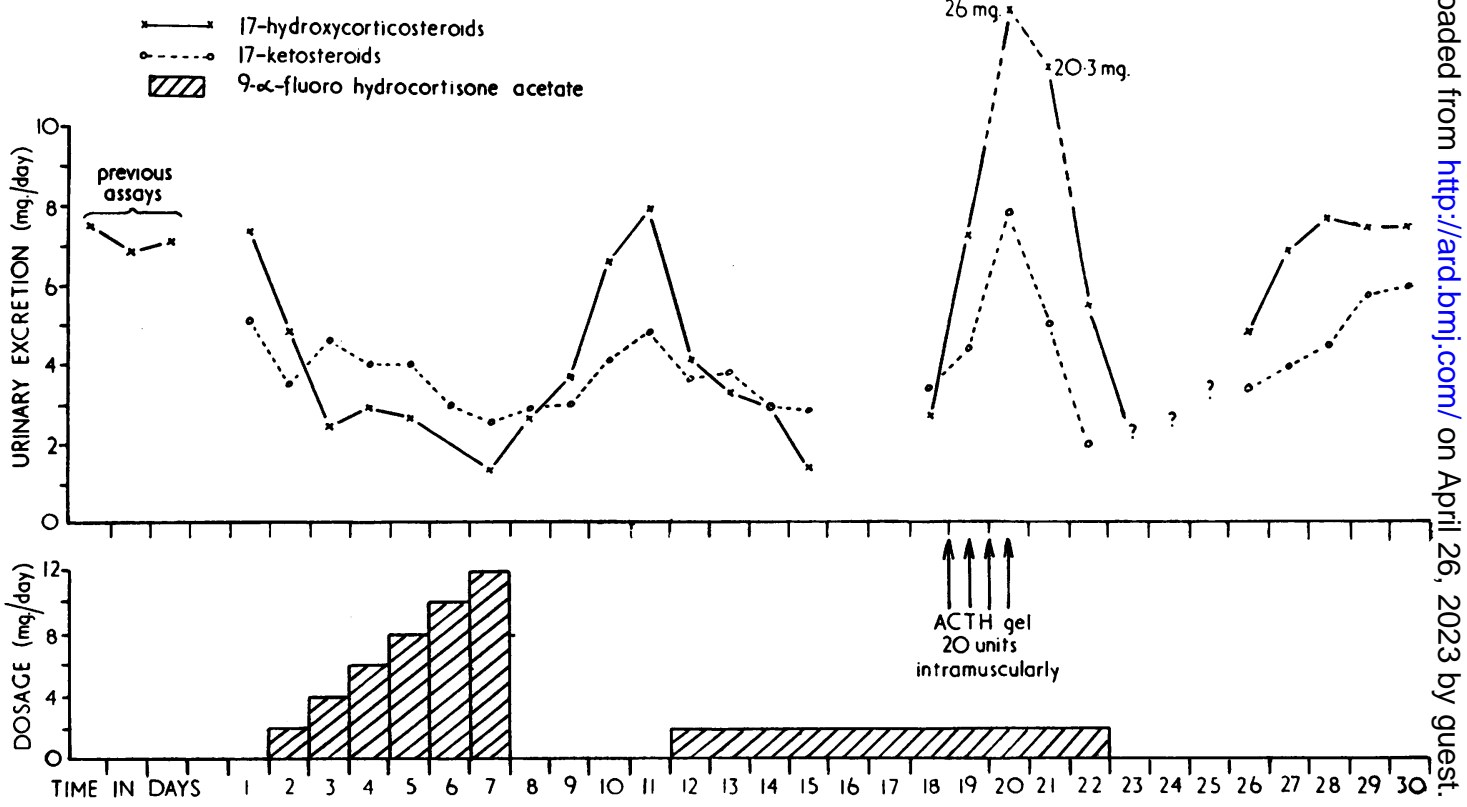

Figure.-Effect of 9- $a$-fluoro hydrocortisone acetate (given orally to a woman aged 29 with rheumatoid arthritis) on adrenal function measure by daily urinary excretion of 17-hydroxycorticosteroids. 
designed to throw light on this question. The patient had early rheumatoid arthritis. She was on a salt-free diet, to minimize fluid retention, during the first period of treatment, but not during the second. The urinary "total 17-hydroxy-corticosteroids (17-OH CS)" assay used was that developed by Dr. J. K. Norymberski at this Centre (Appleby and others, 1954, 1955). The figures recorded on the diagram for 17-OH CS represent the number of $\mathrm{mg}$. excreted daily, less the theoretical recovery, as 17-OH CS, of the administered 9- $\alpha$-fF ( 40 per cent.). The patient's control assays show a below average output of 17-OH CS, representing an endogenous secretion of approximately $20 \mathrm{mg}$. hydrocortisone a day. The results show that as little as $2 \mathrm{mg}$. 9- $\alpha-f F$ profoundly suppresses the endogenous secretion, suppressing it to the same extent as would ten times as much hydrocortisone. That the suppression was mediated through the inhibition of pituitary ACTH is shown by the excellent response to the administration of ACTH.

\section{Summary}

The substitution of a fluorine atom at the 9- $\alpha$ position in the hydrocortisone molecule enhances its ability to suppress adrenocortical function through pituitary ACTH inhibition. The degree of enhancement parallels that of its anti-rheumatic potency.

Thanks are due to Mr. R. D. Stubbs for the chemical assays, and to Dr. Elmer Alpert of Merck and Company Inc. for the 9- $x$-fluoro hydrocortisone acetate.

\section{REFERENCES}

Appleby, J. I., Gibson, G., Norymberski, J. K., and Stubbs, R. D. (1954). Biochem. J., 57, xiv.

Boland, E. W., and Headley, N. E. (1954). Annals of the Rheumatic Diseases, 13, 291.

Effet de l'acétate de 9-a-fluoro hydrocortisone sur la fonction surrénale

\section{RÉSUMÉ}

La substitution d'un atome de fluor en position 9- $a$ de la molécule $\mathrm{d}$ hydrocortisone renforce sa faculté de supprimer la fonction corticosurrénale par l'inhibition pituitaire de l'ACTH. Son pouvoir antirhumatismal est renforcé au même degré.

\section{Efecto del acetato de 9-a-fluoro hidrocortisona} sobre la función suprarrenal

\section{SUMARIO}

La substitución de un átomo de fluor en posición 9- $a$ de la molécula de hidrocortisona acrecenta su poder supresor de la función adrenocortical por inhibición pituitaria de la ACTH. Su poder antirreumático sube paralelamente. 